\title{
Passage rate of liquid and particles in the digestive tract of dairy cows fed fresh forage
}

\author{
M Mambrini, JL Peyraud \\ INRA, Station de Recherches sur la Vache Laitière, \\ Saint-Gilles, 35590 L'Hermitage, France
}

The effect of age of regrowth of perennial rye-grass on the passage of liquid and particles through the digestive tract of 4 fistulated, late lactating or dry cows was studied over 2 successive periods and compared with data previously obtained on conserved forage (Peyraud et al, 1989).

Fresh forage $(F)$, cut late June and mid July (28 and 49 days 1 st regrowth), was given ad libitum with $2 \mathrm{~kg}$ concentrate (C) in 3 meals. Mean retention times in the total digestive tract (TMRT) of $F$ and $C$, respectively labelled with europium and dysprosium, were calculated from the total quantities of markers excreted in the faeces. Rumen liquid turnover rate (K1) and volume (vol) were estimated using dilution of PEG.

Nitrogen content $(\mathrm{N})$ and organic matter digestibility (OMD) decreased with the age of regrowth, but OM intake remained unchanged. The age of regrowth did not significantly affect $\mathrm{K} 1$ or vol although total water intake (TWI) was reduced by $30 \%$ in the older grass. The age of regrowth did not modify TMRTC but TMRTF was increased slightly. Grass TMRT showed large between-cow variation $(7.6 \mathrm{~h}$ ) and increased up to $8 \mathrm{~h}$ with the older grass only in the 2 cows having the shortest TMRTF. Individual TMRTF were correlated with $O M$ intakes $(r=-0.83)$ and with individual variations of ADF digestibility $(r=0.90)$. Compared to winter diets (rye-grass hay, grass and maize silages), $\mathrm{K} 1$ was much higher with fresh grass diets (17 vs $12 \% / \mathrm{h}$ ). Retention times of highly digestible fresh grass (28 $\mathrm{d}$ regrowth) and of its associated concentrate were shorter than those of $F$ and $C$ of winter diets (57 and $41 \mathrm{~h}$ respectively for $F$ and $C$ ). With fresh grass, TMRTC was related to TMRTF $(r=0.78)$ as observed with the conserved forage.

Peyraud JL, Mambrini M, Rulquin H (1989) Asian Australas J Anim Sci 2 (3), 366-367

Table I. Intake and mean retention time of liquids and particles in the digestive tract of dairy cows.

\begin{tabular}{ccccccccc}
\hline $\begin{array}{c}\text { Regrowth } \\
\text { (days) }\end{array}$ & $\begin{array}{c}\mathrm{N} \text { (g/kg OM) } \\
\text { OM intake } \\
(\mathrm{kg})\end{array}$ & OMD & $\begin{array}{c}\text { TWI } \\
(1)\end{array}$ & $\begin{array}{c}K 1 \\
(\% / h)\end{array}$ & $\begin{array}{c}\text { Vol } \\
(1)\end{array}$ & $\begin{array}{c}\text { TMRTF } \\
(\mathrm{h})\end{array}$ & $\begin{array}{c}\text { TMRTC } \\
(\mathrm{h})\end{array}$ \\
\hline 28 & $28.5^{\mathrm{a}}$ & 12.4 & $0.784^{\mathrm{a}}$ & $91.5^{\mathrm{a}}$ & 15.9 & 63.6 & 47.4 & 36.7 \\
49 & $18.2^{\mathrm{a}}$ & 12.7 & $0.733^{\mathrm{a}}$ & $63.8^{\mathrm{a}}$ & 17.3 & 69.6 & 51.6 & 34.5 \\
\hline
\end{tabular}

a. Means in the same column followed by different letters are statistically different $(P<0.01)$. 